\title{
Research on the Construction of "Ideological-Political College English Curriculum" under the Guidance of PBL —A Case Study on New Standard College English Integrated Course 3
}

Guoping An*

Foreign Language Institute of North China Electric Power University, Baoding, Hebei, China

\author{
DOI: $10.36348 /$ sijll.2020.v03i09.005
}

| Received: 15.09 .2020 | Accepted: 24.09 .2020 | Published: 30.09 .2020

*Corresponding author: Guoping An

\section{Abstract}

In order to implement the fundamental task of morality education in China, the teaching team of New Standard College English Integrated Course 3 in NCEPU (Baoding) carries out a research on the construction of "ideological-political curriculum" under the guidance of PBL. The teaching team probes into the methods of integrating the ideological and political elements into the teaching objectives, and designs the teaching activities and evaluates teaching effect accordingly so as to provide reference for the ideological and political construction of other College English courses in China.

Keywords: Ideological-political curriculum; PBL (Project-based Learning); New Standard College English Integrated Course 3; research.

Copyright @ 2020: This is an open-access article distributed under the terms of the Creative Commons Attribution license which permits unrestricted use, distribution, and reproduction in any medium for non-commercial use (NonCommercial, or CC-BY-NC) provided the original author and source are credited.

The necessity and teaching current situation of ideological and political course construction in College English

In order to implement general secretary $\mathrm{Xi}$ Jinping's important exposition on education, domestic universities have promoted the ideological and political reform in curriculum by integrating each other, and exerted the function of educating.

On one hand, as a compulsory course of general education in universities, College English course bears the following features: it covers a wide range of courses; the learning time lasts long; teaching materials are westernized, and students are vulnerable to the influence of Western unhealthy cultural trends. Therefore, College English teaching shoulders responsibility of the ideological and political education and it is necessary to construct new College English curriculum.

On the other hand, from the perspective of current situation of College English teaching, the following problems have existed: the teaching resources of ideological and political education are not systematic as well as the integration is insufficient; the current traditional teaching mode cannot guarantee the students' participation in ideological and political education. If these problems cannot be solved, it is bound to lead to the hard implantation of ideological and political elements in curriculum. As a result, the effect of morality education will be greatly compromised. Therefore, as a kind of invisible curriculum, the ideological and political construction of curriculum needs to combine the "invisible" educational concept and thinking mode with the effective "explicit" teaching mode, so as to truly have the educational effect.

The current situation of the research on the construction of "Ideological and Political Courses" in College English

Combined with the current situation and necessity of ideological and political education, our teaching team has done relevant research on the domestic ideological and political curriculum in recent years. It is found that in the early stage of ideological and political curriculum reform, the research mostly focuses on the value implication and practical path of ideological and political curriculum reform $[1,2]$; after 2018, the ideological and political curriculum reform has entered a critical stage, and more and more colleges and universities have been engaged in this field. From the macro perspective, it mainly focuses on the feasibility, necessity and strategy research of College English curriculum, emphasizing the improvement of teachers' ideological and political ability, in-depth excavation of educational elements, and discussion of 
implementation links [3, 4]; at the micro level, it explores the implementation of specific courses in combination with specific teaching theory [5]. On the whole, these articles organically combine "ideological and political education" with college English teaching, focusing on the value connotation, path analysis, and concept research and macro construction level. However, the ideological and political construction of curriculum is not implemented with specific and effective teaching mode, which needs further research and exploration.

\section{Research status of PBL (Project-based Learning) teaching mode}

PBL teaching mode is based on the theory of constructivism learning and social culture interaction [6]. It is found that the research and application of PBL in the West can be dated back to the 1990s, and now it is widely used in Europe and North America. The research on PBL in China started late. At present, most domestic articles on PBL focus on basic concepts, characteristics, elements and implementation, such as comprehensive research on PBL in college English and other teaching modes (blended teaching, flipped teaching, etc.) [7]; empirical research on PBL and different English courses teaching [1,8]. These papers show that the introduction of PBL teaching mode in College English teaching can play a good role in promoting the main role of students and guiding the cultivation of students' ability.

The research group found that PBL teaching mode bears the following feature "teacher-oriented, students-centered, project-driven, and abilitycultivated". The outstanding characteristics of PBL can effectively solve the problems in the ideological and political construction of College English course: its practicability and reality are in perfect agreement with the educational goal of ideological and political education; its student-centered project design, team cooperation and other characteristics can well implement the ideological and political elements in practice; its standards and evaluation system can measure and test the students' education effectiveness and so on. As a result, the combination of PBL and College English curriculum will greatly promote the ideological and political construction and put it into practice.

Therefore, PBL is proposed to apply to the College English teaching process. Through the organic integration of ideological and political education and project, the teaching mode with the characteristics of student-centered, active participation, practical cooperation and diversity of evaluation can effectively solve many problems in current ideological and political curriculum, and carry out the corresponding ideological and political construction
A Case study on the combination between PBL and ideological and political course of College English

College English is a compulsory course for all majors in North China Electric Power University (Baoding). It usually has 64 class hours in the first semester. The current textbook is "New Standard College English Integrated Course 3". The research group adopts PBL teaching mode in the teaching class with the capacity of 50 students to carry out the goal planning, teaching design, teaching implementation and evaluation of ideological and political course construction.

\section{Goal planning}

The socialist core values have three levels, namely, national, social and individual level. The research group sets up three levels of goal for "ideological and political curriculum" corresponding to socialist core values respectively. The research group aims to probe the morality elements in multi-level and multi-dimensional way, and clarify the content of ideological and political education

The elements of ideological and political education at the national level are analyzed as spreading the advanced culture of the times and excellent traditional culture, highlighting the great achievements of China's socialist construction, such as China's economy, politics, science and technology, enhancing national self-esteem and pride, and disseminating positive social energy.

The elements of ideological and political education at the social level are analyzed as the pursuit of freedom, equality and legal system, and the construction of a harmonious, civilized and beautiful living environment.

The value criterion of citizen's individual level is to spread positive energy, win-win thinking, altruistic spirit and the thought of being kind to others.

\section{Teaching design}

According to the goal planning of the above, the research group adopts PBL teaching mode and combines ideological and political elements in teaching design. Through the total project task of "People and Society" for 1st semester, the ideological and political work runs through the whole process of English teaching, including the introduction and expansion of project themes, teaching links and text teaching after class project and task output.

The teaching design combines the unit theme content and ideological and political elements in the textbook. Five unit themes are selected from the eight units of New Standard College English Integrated Course 3 for the freshmen of 2019, including: "comparison of festival culture between China and the west" (National level), "social value of art" and "race 
and social equality" (Social level), "human value and significance" and "children's frustration education" (individual level). On this basis, it was planned to carry out the exhibition of the general theme of "People and
Society" at the end of the semester (integrating cultural self-confidence, construction of socialist characteristics and development of personal education). Refer to table 1:

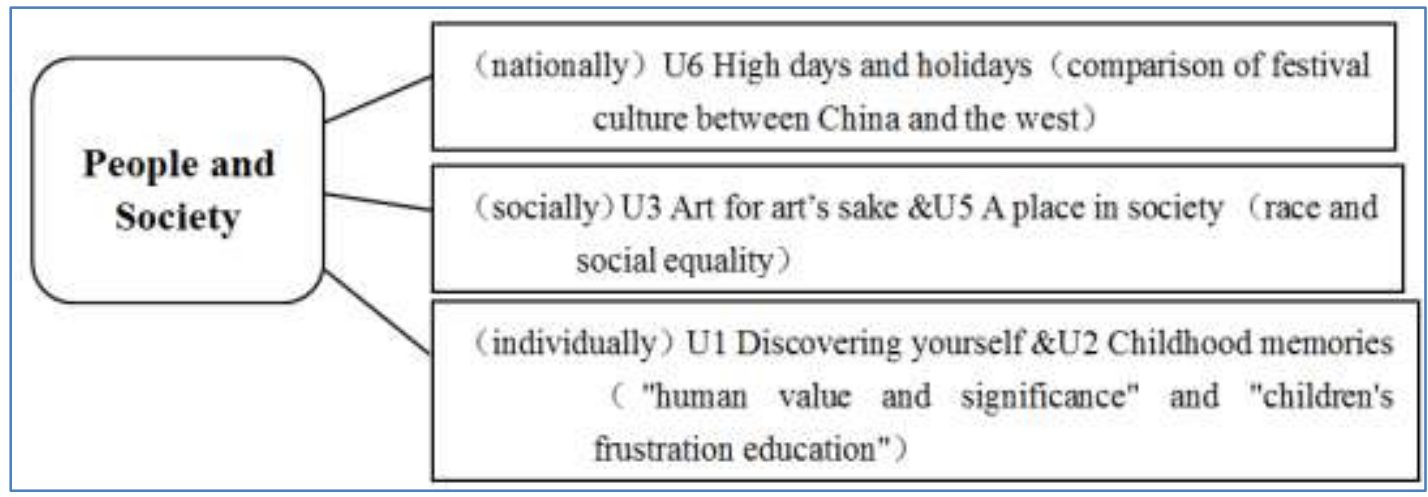

\section{Teaching Implementation}

PBL teaching mode is adopted to integrate the ideological and political elements into English teaching. With the help of scaffolding teaching, students are inspired to develop their ability of independent project planning and design, active learning and cooperation.
Combined with the characteristics of teachers' guidance, standardized project criteria, effective classroom management and diversified evaluation system, ideological and political elements are delicately integrated into all aspects of College English. Refer to Table 2.

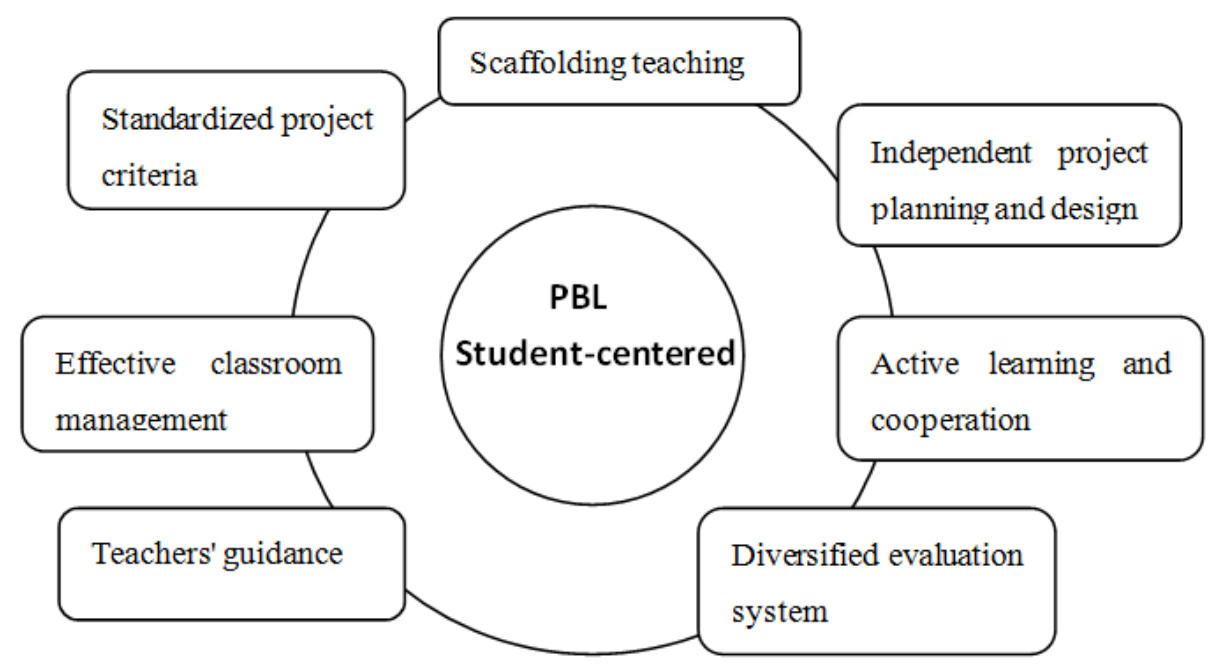

\section{Concrete Process}

The teaching team divides each unit into three parts: pre-class preparation, classroom teaching and after-class activities.

In the pre-class preparation stage, teachers adopt the form of flipped classroom, using the network, QQ and wechat group and other modern information interaction means to release video materials related to the course content.

Classroom teaching generally follows the steps of course introduction, target display (teachers will emphasize the ideological and political goals to be achieved), difficult points and project assignment. The whole teaching is student-centered, and the classroom teaching mode of "Teaching (teacher) + demonstration (teacher or student) + cooperation $($ student $)+$ project (student)" is realized through theme discussion.

After-class activities focus on project. In the project (3-4 students), each student is guided by the principle of PBL (project-based learning). The following are concrete steps:

Step 1: Students develop their own specific sub themes on the basis of the major themes of the ideological and political projects designated by the teachers.

Step 2: Teachers and students jointly formulate the expected project results, such as cultural display boards, videos, posters, research reports, etc. 
Step 3: Teachers and students jointly plan the project and implement it, including project objectives and tasks, steps and procedures, methods and contents, cooperation and division of labor arrangement.

Step 4: Teachers should provide students with language, skills and strategies for project material collection.

Step 5: Students collect relevant material information, such as network resources, research and so on.

Step 6: Teacher arranges and analyzes the materials for students, and supports them in language, skills and strategies.

Step 7: Students organize and analyze the collected material information.

Step 8: Teacher supports students in language, technology and strategy.

Step 9: Students present the project results.

Step 10: Evaluate the project results.

\section{An Example taken from New Standard College English Integrated Course 3}

Take U1 Catching crabs as an example. The teaching team set two teaching goals

Internal goal is to develop students' sense of self-knowledge and prepare them well for the future career and life; to embrace the culture of supporting one another in team rather than dragging down each other. External goal is to inspire students to use analogy in effective communication and to enable students' project-based skills when creating and conducting a survey on "What to Do after Graduation".

Accordingly, the teaching team sets two "ideological-political goals": Individually, to inspire students to pursue self-value and stay true to themselves, and empower them with right decisions and never-yielding spirit for their dream and happiness. Collectively, to understand the defining power of unity and solidarity in pursuit of success.

In order to realize the above goals, the teaching team adopts PBLwhich will be integrated to engage students in solving real-world dilemmas after graduation and answering their driving questions in decision making. The teaching strategy is listed here:

1) Project (in groups of 3-4) --- to design and conduct a college survey on students' plans after graduation, and present it in class in various forms.

2) It is student-driven, and students are responsible for making choices and for designing and managing their work with teacher's guide.
3) "Learning by doing" can better prepare students with life skills that set them up for future success, and provide students with the opportunities to internalize knowledge into application and deep understanding.

4) Students take ownership over their projects, reflecting on and celebrating their progress and accomplishments, which naturally enhances their selfconfidence and helps to find their true values.

\section{EVALUATION \& CONCLUSION}

For the first graders, it is quite rewarding to navigate them to set goals by engaging into the project of designing a survey on graduation plan. Meanwhile, team spirit of communication and collaboration has been on the rise in the process of survey planning and conducting. However, some students feel overwhelmed due to the lack of technical experience with digital apps, devices or survey format, inadequate with survey making. Teachers should provide them with sufficient and immediate online technical assistance. More importantly, to enhance their awareness of self-value, it is advisable to provide appropriate guidelines for the width, depth and warmth of their surveys.

This is an age with innovative thought and creative idea rather than memorizing knowledge points. In College English class, through participatory, cooperative and interactive activities in and out of class, students not only improve their professional quality and communicative ability, but also form a good character and socialist core values. Their performance fully reflects the teaching effect of the combination of ideological and political education and English curriculum under the guidance of PBL.

\section{ACKNOWLEDGEMENT}

This research is financially supported by Research Project of English Teaching Reform of Higher Education in Hebei Province (2020YYJG046); Project of Promotion and Demonstration Plan for Excellent Teachers in North China Electric Power University (Baoding) (Grant NO. 13001904).

\section{REFERENCES}

1. Gao, Y. (2010). Research on the Application of Project-based Learning in College English Teaching [J]. Foreign Language World,6

2. Xiao, X., Zhu, Z. (2018). Exploration and Practice of ideological and Political Curriculum Education [J]. Ideological and Theoretical Education Guide, 10

3. Liu, X. (2018). Research on the Ideological and Political Curriculum of College English [J]. Journal of Jilin Institute of Business and Technology, 5

4. Lu, J. (2019). Exploration on the feasibility of promoting "Curriculum Ideology and politics" in College English Curriculum [J]. Journal of Shanghai Second University of Technology, 6:130

5. Wang, B. (2013). Analysis on Factors of PBL on College English Learning Motivation [J]. 
Computer-assisted Foreign Language Education, 1

6. Gao, N., Zhang, M. (2018). Analysis of "Curriculum Theory" on Construction of "Ideological and Political Curriculum" [J]. Chinese university teaching, 10

7. Ren, Y. (2020). Research on Hybrid Teaching Mode of Business English based on PBL [J].
Journal of Chongqing Vocational College of Electronic Engineering, 2

8. Wang, H. (2019). Research on the Integration of "Ideological and Political Curriculum" based on Ubiquitous Learning Environment [J]. Education and Teaching Forum, 1. 